\title{
A new species of Paramyopa KRöBER (Diptera: Conopidae) from South Africa
}

With 7 figures

Jens-HeRMANn StUKE ${ }^{1}$

1 Roter Weg 22, 26789 Leer, Germany. - jstuke@zfn.uni-bremen.de

Published on 2021-06-30

DOI:10.21248/contrib.entomol.71.1.161-165

\section{Abstract}

Paramyopa clementsi spec. nov. (Diptera, Conopidae) is described from South Africa (Northern Cape), and its diagnosis from the two other known species of this Afrotropical genus is set out.

\section{Nomenclatural acts}

Paramyopa clementsi spec. nov. - urn:lsid:zooank.org:act:28720591-141E-46D8-AFDA-3922BCE0BD48

\section{Key words}

Diptera, Conopidae, Paramyopa, new species, South Africa, Apidae, Patellapis, potential host

\section{Zusammenfassung}

Paramyopa clementsi spec. nov. (Diptera, Conopidae) wird aus Südafrika (Nordkap) beschrieben, und ihre Abgrenzung von den beiden anderen bekannten Arten dieser afrotropischen Gattung wird dargelegt.

\section{Schlüsselwörter}

Diptera, Conopidae, Paramyopa, neue Art, Südafrika, Apidae, Patellapis, potentieller Wirt

\section{Introduction}

Paramyopa is an Afrotropical conopid genus containing two described species to date (Stuke 2017). The distribution of these species is disjunct, with $P$. insignis (JAENNICKE, 1867) being recorded once only from Ethiopia and P. oestracea (Loew, 1863) recorded from Lesotho, Namibia and South Africa. Their biology and immature stages are unknown. Whilst visiting the
Natural History Museum (London) to study type specimens of Afrotropical Conopidae, David Clements drew my attention to two unusual Paramyopa specimens held in the collections there. These specimens proved to belong to a third, previously unknown Paramyopa species which is described below. 


\section{Material and methods}

Terminology for the species descriptions is mainly adopted from Cumming \& Wood (2017). The term "hair" is replaced by "setula" since it is not possible to distinguish between genuine hairs and setulae. The term "seta" is used only where the structure is clearly stronger and more robust than the surrounding setulae, or it can be identified as one of the known setae of the acalyptrate chaetotaxy. Numbers of setae refer to one side of the body only. For any form of microtomentosity the more common term "dusting" is used. Abdomens were not dissected due to the rarity of the available material and the unambiguous diagnosis of the species. The male terminalia is therefore not described. Labels are listed and numbered in the order found, commencing with the uppermost. Line-breaks on labels are indicated by a slashmark " / " and where there are actual slash-marks on the labels themselves these are included without spaces before and after. Photos were made with a Nikon D500 mounted on an Olympus SZX16 binocular with indirect LED lightning. Stacking was made with Helicon Focus 7.6.

\section{Results}

\section{Paramyopa clementsi spec. nov. urn:Isid:zooank.org:act:28720591-141E-46D8-AFDA-3922BCE0BD48 (Figs 1-7)}

Holotype ( $\left(^{\star}\right)$ : (1) “S. Africa, Nieuwoudtville / Flower Reserve dolerite / flats, $750 \mathrm{~m}$, nesting site, / S $31^{\circ} 22^{\prime} 10.8^{\prime \prime} / \mathrm{E} 19^{\circ} 08^{\prime} 50.2^{\prime \prime} /$ K. Timmermann, 8.IX.2007"; (2) "Kuhlmann \& / Timmermann coll. / BMNH(E) 2010-148"; (3) "NHMUK 010922182"; (4) "Holotypus / Paramyopa / clementsi spec. nov. / Stuke des. 2020". Holotype is pinned, complete and in a good condition. It is deposited in the Natural History Museum, London (NHM).

Paratype ( $\left.0^{*}\right)$ : (1) "S. Africa, Northern Cape, / Nieuwoudtville Wild / Flower Reserve, 770 m / S 3122'25"/E 1908'46" / K. Timmermann, 10.IX.2007"; (2) "Kuhlmann \& / Timmermann coll. / BMNH(E) 2010-148"; (3) "NHMUK 010922181"; (4) "Paratypus / Paramyopa / clementsi spec. nov. / Stuke des. 2020"; private collection J.-H. Stuke (PJHS).

Description of male Holotype: Length $11.3 \mathrm{~mm}$. Winglength $8.3 \mathrm{~mm}$. Head-height $3.6 \mathrm{~mm}$.

Head: Basal flagellomere black. Scape and pedicel light brown to dark brown. Arista with 3 dark brown aristomeres situated dorsally on the basal flagellomere. Arista hardly longer than basal flagellomere, steadily narrowing towards apex. Scape slightly longer than broad, apically with short setae only. Pedicel about twice as long as scape, completely covered with short black setae and indistinct silver dusting. Basal flagellomere about as long as high, completely grey dusted.
Lunule between base of antennae and ptilinal suture almost completely invaginated. Posterior margin of eye convex, lacking any indentation. Genal height of head / eye height (measurements taken from head in lateral view $)=0.7$. Ocellar tubercle with three distinct orangebrown to dark brown ocelli. Ocellar triangle evident, about half as long as frons. Ocellar triangle shining, with dusting in anterior $1 / 3$. Frons longer than broad, flat, not projecting above eyes, slightly silver dusted all over and with scattered black to brown setae. Frons yellow, brownish lateral of ocellar triangle and anterolateral. No frontofacial spots. Face yellowish-white, with an indistinct brownish spot beneath antennal base. Face slightly silver dusted. Gena yellowish-white, with a distinct brown spot at posterior margin of eye. On left gena only (of holotype) there is also a small brown spot beneath the upper spot. Parafacia with large brown spot between anterior margin of eye and antennal base. Gena and facial ridge without setae. Facial grooves reaching to large tubercle in ventral face. Facial carina not evident. Ptilinal suture stretching beneath antennal bases. Postcranium whitish-yellow, dorsally light brown and lacking any brown spots. Postcranium microtomentose all over, but without obvious denser dusting along eye margin. Yellow hairs in ventral $2 / 3$ of postcranium and black hairs in dorsal $1 / 3$. No hairs on a small area adjacent to eye margin or on the bottom portion of postcranium. Median occipital sclerite with a few scattered black hairs ventrally. Postgena widened and delimited from the narrow occiput. Proboscis black; an indistinct brown spot present between frontoclypeal membrane and mouth edge. Frontoclypeal membrane narrow, broadened basally, white and distinctly delimited from the small brown clypeus. Palp long (more than half length of labellum) black, hardly widened distally, and covered with long black hairs. Prementum shorter than maximum head-length, hardly projecting out of mouth opening, slightly thickened basally. Labellum as long as prementum, divided at apex only, slightly narrower than prementum and covered with scattered setulae apically. Head with 1 long ocellar seta, 1 small postocellar seta, 2 distinct medial and 1 lateral postocular setae.

Thorax: ground colour black to brown. Scutum black with brown margins. Pleura brown, with black on anepisternum, anepimeron, katepisternum and katepimeron. Mediotergite black. Thorax entirely light grey dusted, only anepisternum and katepimeron with shining patches and mediotergite shining in ventral half and medially. Scutum with two pairs of matt blackdusted spots. Presternum only a narrow sclerotised stripe. Basisternum triangular, with about 20 black setae dorsolaterally. Proepisternum with a tuft of about 35 black setae ventrally, and no setae dorsally. Scutum with black setulae which are slightly shorter than tibia diameter. Some strong setae are obvious in between the setulae of scutum, and these might represent typical setae of acalyptrate chaetotaxy: 0 postpronotal, 
3 notopleural, 2-3 supraalar and 3-4 postalar setae. Setae and setulae of postalar callus restricted to anterior half, posterior half of postalar callus lacking any setae or setulae. About 40 black setulae posterodorsally, and about 15 setulae ventrally, on katepisternum. Metakatepisternum without setae. Anepisternum and anepimeron without setae or setulae. Mediotergite slightly convex, hairless, and shorter than scutellum. Subscutellum inconspicuous. Scutellum with lateral tufts of setulae, and bare medially. 3-5 scutellar bristles present along posterior margin on each body side, located behind the lateral tufts of setulae.

Wing tinged inconspicuously brownish. Radial cell $\mathrm{r}_{4+5}$ with a darkened central spot. Base of wing and area surrounding of crossvein bm-cu both whitish, and veins there yellow. Dark brownish colouration extends between these two paler areas, and extends as dark brown colouration extending into subcostal cell sc. Alula contrasting whitish-yellow. Wing membrane completely covered with microtrichia. Radial-medialcrossvein r-m complete. Basal-medial-cubital-crossvein bm-cu incomplete. Radius $\mathrm{R}_{1}$ and subcosta terminate almost together in the costa, well before the end of Radius $\mathrm{R}_{2}$. $\mathrm{R}_{1}$ not touching the subcosta and terminating in the costa. Distal section of Radius $\mathrm{R}_{4+5}$ shallowly and evenly curved towards the fore-edge. Radial cell $\mathrm{r}_{4+5}$ open, vein $\mathrm{R}_{4+5}+\mathrm{M}$ not expressed. Cubital cell cup slightly elongated (about as long as vein $\mathrm{A}_{1}+\mathrm{CuA}_{2}$ ) and pointed distally (cubitus $\mathrm{CuA}_{2}$ and anal vein $\mathrm{A}_{1}$ meet at an acute angle). Vein $\mathrm{A}_{1}+\mathrm{CuA}_{2}$ reaching hind margin of wing. Cubital vein $\mathrm{CuA}_{1}$ and crossvein bm-cu distinctly separated. Upper and lower calypters white, upper calypter with moderately long white hairs on margin (distinctly shorter than maximum length of calypter). Alula broad, about 2 times broader than long, without hairs on posterior margin. Venae spuriae pronounced in cubital cell cup, in discal medial cell $\mathrm{dm}$ and in radial cell $\mathrm{r}_{4+5}$. Haltere brownish with a black, grey-dusted knob. Knob of haltere with short, indistinct, light yellow hairs.

Legs light brown with femora black apically, and tibiae black medially. Legs lightly dusted all over and with obvious, irregular silver dusting on fore and middle femur and restricted silver dusting apically on hind femur. Posterior surfaces of fore and middle tibiae without obvious dusted fields. Legs all with long, semiadpressed or erect black setulae. Dense brown setulae ventrally at tip of fore tibia and ventrally and posteriorly at tip of hind tibia. Additional dense black setulae dorsally at base and at middle of all tibiae. Hind femur ventrally and dorsally with outstanding long setulae. 1 praeapical seta dorsally on each tibia. Tibiae and femora lacking obvious lines of small, thick, adpressed black setulae, but middle and hind tibiae with slightly thicker and shorter setulae between the long pile that might represent these setae. All coxae with dense, long black setulae but no outstanding setae. Hind femur not obviously thickened in the basal half. Tibiae all abruptly thickened in the apical 2/3. All metatarsi with denser black setulae apically and basally, giving them a striped appearance. Pulvilli yellowish-white. Claws orange, with black tips. Empodium yellow-brown. Empodium about as long as pulvilli.

Abdomen: ground colour black, with hind margins of tergites 4-5 narrowly brownish and sternite 8 and terminalia orange-brown. Abdomen mostly silver-white dusted, with an irregular dusting pattern laterally and a slightly less dusted stripe medially on tergites 3-5. However, this dusting depends very much on viewing angle. Abdomen covered with semiadpressed black setulae, tergite 2 laterally with distinctly longer black setulae than on other tergites. Tergite 1 without bulbous lateral projections.

Variability: The paratype differs in these respects: Winglength $9.1 \mathrm{~mm}$. Ocellar triangle almost completely dusted. Some small brownish spots on gena and parafacia. Both fore femora are deformed. Mediotergite more dusted, and also with a shining medial area. One hind tibia has two praeapical dorsal setae. Hind margins of tergites 4-5 broader brownish.

\section{Female unknown to date.}

Diagnosis: Paramyopa clementsi is easily distinguished from the only two known Paramyopa species by (i) its characteristic wing colouration, with a distinct spot in radial cell $\mathrm{r}_{4+5}$, paler wing base and whitish field around crossvein bm-cu (Fig. 7), (ii) its black to brown scutum, with two pairs of matt black spots (Figs 1,5) and (iii) its black abdomen with short black hairs, and lacking any emarginations (Figs 1,6). Using the key of STUKE (2015) for the previously described Paramyopa species, $P$. clementsi will not run to either alternative.

Etymology: This species is dedicated to David $\mathrm{K}$. Clements, who first drew my attention to it. I also wish to take this opportunity to acknowledge our long friendship and extensive past cooperation in the study of the Conopidae.

Distribution: To date only the locus typicus and the nearby location of the paratype are known. Both locations lie in the South African Bokkeveld Plateau of the Northern Cape.

Ecology: The locus typicus is decribed in TimmerMANN \& KuHLMANN (2008: 190): "the Nieuwoudtville Wild Flower Reserve $\left(31^{\circ} 21^{\prime} \mathrm{S} 19^{\circ} 08^{\prime} \mathrm{E} ; 760 \mathrm{~m}\right)$ [is] in the South African winter rainfall area. Climatically, the Nieuwoudtville area is semi-arid with a mean annual rainfall of $341 \mathrm{~mm}$. The reserve falls within the vegetation type of the Nieuwoudtville dolerite renosterveld and is renowned for its high diversity of geophytes and annuals". The type specimens of $P$. clementsi were 

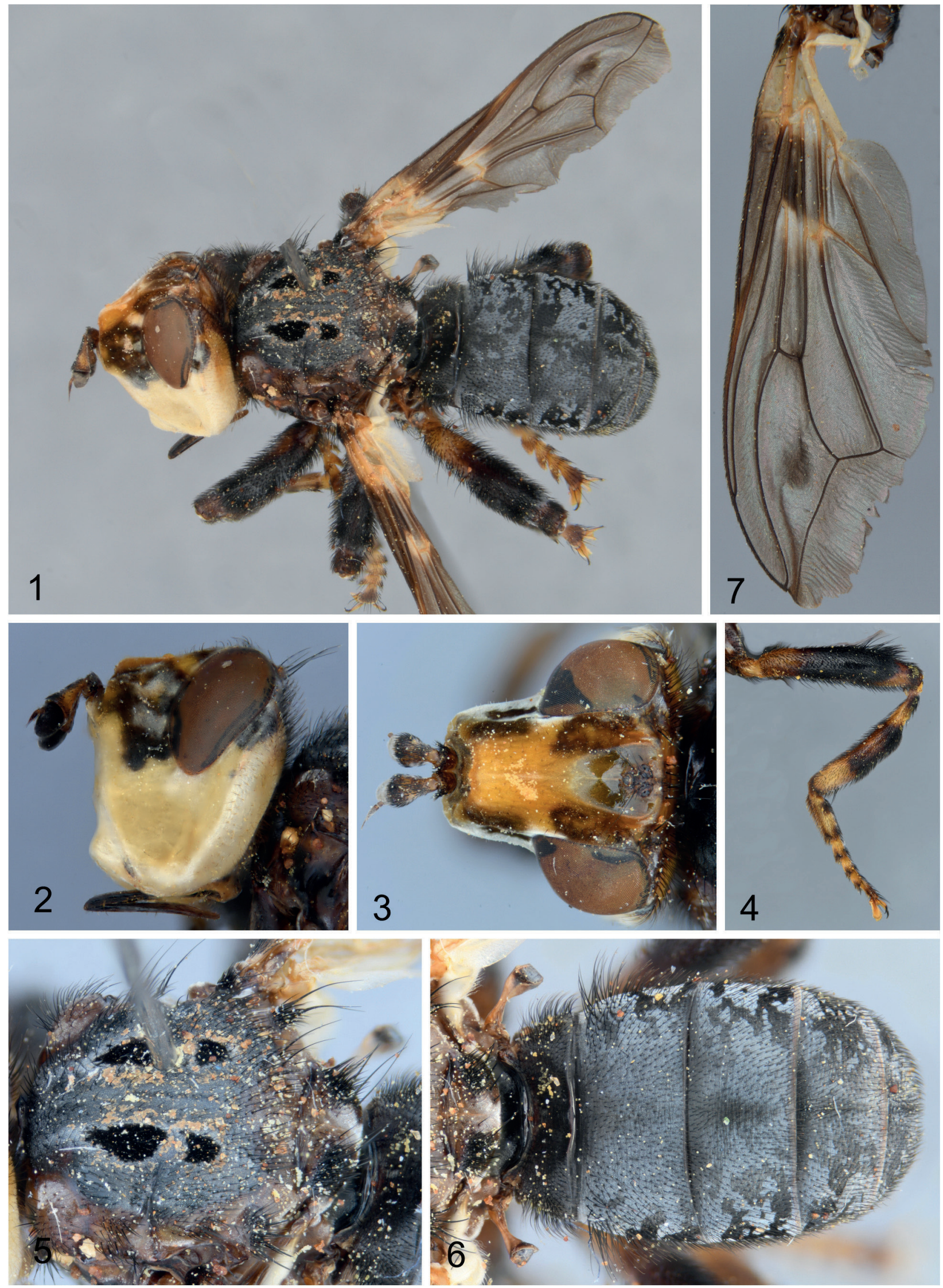

Figs 1-7: Paramyopa clementsi spec. nov. ( $\sigma^{\top}$ holotype). 1 habitus, dorsolateral view; 2 head, lateral view; 3 frons, dorsal view; 4 hind tibia, anterior view (paratype); 5 scutum and scutellum, dorsal view; 6 abdomen, dorsal view; 7 wing, posterior view. 
both collected near nesting sites of the bee Patellapis (s. str.) Friese, 1909 (Hymenoptera, Apidae). This Afrotropical genus includes several species which could reasonably comprise hosts for Paramyopa. Several Patellapis species occur at the locus typicus (TImMERMAnN \& KuHLMann 2009). Both type specimens were caught in early November, which in South Africa falls within the spring. This might indicate that $P$. clementsi is a vernal species, as is typical for many Palaearctic species of the closely related genus Myopa.

\section{Acknowledgements}

Michael Kuhlmann (Germany, Kiel) and Kim Timmermann (Germany, Münster) gave me information about the collecting site of $P$. clementsi, whilst Martin Hauser (USA, Sacramento) patiently explained how to improve the quality of the pictures. I thank David Clements (UK, Cardiff) for first drawing my attention to the specimens described here, and for checking the manuscript and making several important remarks.

\section{Literature}

Cumming, J. M. \& Wood, D. M. 2017: Adult morphology and terminology. - Pp. 89-133. - In: KIRKSpriggs, A.H. \& Sinclair, B. J. (eds.): Manual of Afrotropical Diptera. Volume 1. Introductory chapters and keys to Diptera families. - Suricata 4: xiii + 1-425.

Stuke, J.-H. 2015: New Conopid records from the Afrotropical Region (Diptera). Part 1: Paramyopa KröBer, Pseudoconops CAMras, Stylogaster MACQUART, Thecophora Rondani, and Zodion LATREILle. - Zootaxa 3963: 101-159.

STUKE, J.-H. 2017: World Catalogue of Insects. Volume 15. Conopidae (Diptera). - Leiden, Boston: E. J. Brill, xxxviii + 354 pp.

Timmermann, K. \& Kuhlmann, M. 2008: The biology of a Patellapis (s. str.) species (Hymenoptera: Apoidea: Halictidae): sociality described for the first time in this bee genus. - Apidology 39: 189-197.

Timmermann, K. \& Kuhlmann, M. 2009: Taxonomic revision of the African bee subgenera Patellapis, Chaetalictus and Lomatalictus (Hymenoptera: Halictidae, genus Patellapis FrIESE 1909). - Zootaxa 2099: $1-188$ 